\title{
On the system of mood in European and Brazilian Portuguese
}

\author{
RUI MARQUES
}

\begin{abstract}
This paper is concerned with mood distribution in European and Brazilian Portuguese. Although, in many cases, these two varieties do not differ as regards the selected mood, there are exceptions in some contexts. The variations involve rather different constructions, at first sight suggesting a chaotic picture. However, if one assumes that mood is associated with the expression of an attitude towards a proposition (in other words, that mood is an expression of modality), it becomes clear that European and Brazilian Portuguese are diverging in respect to the relevant factors for mood selection. In particular, while in European Portuguese the selection of mood is sensitive to both veridicality and epistemic modality, Brazilian Portuguese is becoming a language where the truth-value of the proposition is the main factor responsible for mood selection. Hence, a tendency appears to be developing for Brazilian Portuguese to approach the pattern found in languages like Rumanian, (Modern) Greek or Hungarian, while European Portuguese follows the pattern found in most other Romance languages.
\end{abstract}

\section{Introduction}

In this paper, I will work on differences in mood selection between European and Brazilian Portuguese. In the first section, I will give a general picture of the mood distribution in both varieties of Portuguese; in the next section, I will present the main semantic or pragmatic analyses of mood selection, arguing that none of them gives a satisfactory account of all the facts. I will then propose an analysis based on the claim that mood is a context 
dependent feature and that the indicative is the marked mood. That is, there are modal contexts that indicative is sensitive to, and it only occurs in those contexts. As for the other main mood, subjunctive, it is not sensitive to any particular value, instead occurring in those contexts that do not require the presence of indicative. The differences between European and Brazilian Portuguese derive from the fact that the contexts that indicative is sensitive to are not the same in the two varieties of Portuguese.

\section{Mood distribution in European and Brazilian Portuguese}

In most contexts, European and Brazilian Portuguese do not show differences regarding the selection of mood. However, there are some cases where the mood that is found in one variety is not the same as in the other variety.

The differences to be pointed out are found mainly in complement clauses and in a particular kind of main clauses. Concerning complement clauses, in some of these constructions the selection of subjunctive is obligatory in European Portuguese, but in Brazilian Portuguese the indicative occurs. In other complement clauses the opposite situation obtains, that is, the indicative is selected in European Portuguese, while in Brazilian Portuguese the subjunctive may occur.

Regarding independent or main clauses, both in European and in Brazilian Portuguese, the indicative is the mood most easily found. This follows from the fact that the indicative is obligatorily selected for clauses associated with an assertive speech act. In other words, if the clause expresses a proposition that the speaker presents as one he believes in, indicative must be selected.

However, other moods may also occur in independent clauses. For instance, the imperative mood may occur in independent clauses associated with a directive speech act, as shown by (1):

(1) Corre!

$$
\text { '(You) (do) Run!' }
$$

The subjunctive mood may also occur in independent clauses, provided that they do not allow the inference that the speaker believes in the truth of the proposition expressed. Thus, in independent clauses, subjunctive may occur in imperative sentences, as (2a) or (2b); in expressions of desire or associated notions, as (3); and in declarative clauses under the scope of talvez ('maybe'), as (4):

(2) a. Corra!

'(He) Run!'
b. Não
corras!
not run-2Sg-SUBJ

'(You) Do not run!' 
(3)
Queira
Deus!
Wish-SUBJ
God

'May God so wish'

(4)

$$
\begin{array}{lll}
\text { Talvez ele esteja em casa } \\
\text { maybe he is-SUBJ at home }
\end{array}
$$

'Maybe he is at home'

Still considering independent or main clauses in European and Brazilian Portuguese, a difference may be observed regarding the selection of the conditional mood or the indicative future, with a purely modal value. This difference between the two varieties is related to the conditional mood, as exemplified in (5):

$$
\begin{aligned}
& \text { O fogo teria começado na cozinha. } \\
& \text { the fire have-COND started in-the kitchen }
\end{aligned}
$$

'The fire would have started in the kitchen'

'Allegedly, the fire started in the kitchen'

Out of context, (5) is ambiguous. It may be interpreted as the consequent of a conditional clause, whose antecedent is not verbalised, or it may express a supposition. In other words, in regard to the first interpretation, the truth of the proposition expressed in (5) respects a world (possibly) different from the real one, while in the second interpretation it is the truth of the proposition in the real world that is at stake. It is this second interpretation that matters here, because it provides a piece of evidence that the modal system of European Portuguese and Brazilian Portuguese are becoming distinct.

In Brazilian Portuguese, (5) may describe a situation that the speaker takes as (quite) possible, but not certain. That is, by asserting (5), the speaker says that he has some evidence that the fire started in the kitchen or, at least, that he does not exclude such possibility, though he is not completely sure. This interpretation of (5) is not available in European Portuguese. In fact, in this variety, by asserting (5), the speaker just says that, according to someone else, the fire started in the kitchen. That is, he simply says what other people think that may be the case, not committing himself with the truth-value of the proposition.

Things being so, it may be said that, both in European and in Brazilian Portuguese, the proposition expressed in (5) is not presented as something that the speaker takes for granted. That is, the sentence does not indicate that the speaker believes that, in fact, the fire started in the kitchen. Thus, in both varieties, the conditional mood, in independent sentences, signals a distance of 
the speaker towards the truth of the proposition. However, while in European Portuguese, by selecting the conditional mood, the speaker links someone else with the commitment to the truth of the proposition, in Brazilian Portuguese, the conditional mood may be selected even if the responsibility for the acceptance of such truth is not ascribed to another person. Interestingly, this is the kind of interpretation that, in European Portuguese, is available for sentences like (6), where the future of indicative is found:

(6)

$$
\begin{array}{lllll}
\mathrm{O} \text { fogo } & \text { terá } & \text { começado na } & \text { cozinha. } \\
\text { the fire } & \text { have-IND } & \text { started } & \text { in-the } & \text { kitchen }
\end{array}
$$

'Allegedly, the fire will have started in the kitchen'

In other words, if the speaker wants to express that the proposition he asserts may be true, though he is not certain that it is, in European Portuguese he may select the future of indicative (cf. (6)), while in Brazilian Portuguese he may select the conditional mood (cf. (5)).

If one takes into consideration complement clauses, other differences in mood selection between Brazilian and European Portuguese may be observed. These differences respect the mood that is selected for complement clauses of various kinds of verbs, nouns or adjectives. In the first place, let us observe that nouns like pena 'pity', in sentences like (7a-b), and adjectives like bom 'good', in sentences like (8a-b), obligatorily select subjunctive in European Portuguese, but accept indicative in Brazilian Portuguese:

(7) a. (Que) Bom que ele chegou. [BP

(that) good that he arrived-IND

b. Que bom que ele tenha chegado. [EP] that good that he has-SUBJ arrived

'It is good that he arrived'

(8) a. Pena que ele ainda não chegou. [BP] pity that he yet not arrived-IND

b. É pena que ele ainda não tenha chegado. [EP] is pity that he yet not has-SUBJ arrived

'It is a pity that he has not arrived yet'

In the second place, it should be noticed that some verbs that Farkas (1992) named 'fiction verbs', obligatorily select indicative in European Portuguese, but may select subjunctive in Brazilian Portuguese: 
(9) a. Suponha-se que os padres José de Anchieta e Manuel suppose-it that the priests José de Anchieta and Manuel

$\begin{array}{llclll}\text { da Nóbrega } & \text { comparecessem } & \text { à } & \text { reunião } & \text { que } & \text { a } \\ \text { da Nóbrega } & \text { attend-SUBJ } & \text { to-the meeting } & \text { that the }\end{array}$

Conferência Nacional dos bispos do Brasil realizará

Conference National of-the bishops of-the Brazil realise

em Abril. [BP]

in April

(VEJA, year 33, n. 11, 15 March 2000, 162)

b. Suponha-se que [...] compareciam [EP]

suppose-it that [...] attend-IND

'Suppose that the priests José de Anchieta and Manuel da Nóbrega were to attend the meeting that the National Conference of the Bishops of Brazil will realize next April'

(10) a. Imaginemos que hoje seja domingo. [BP] imagine that today be-SUBJ Sunday

b. Imaginemos que hoje é domingo. [PE] imagine that today is-IND Sunday

'Let us imagine that today is Sunday'

Apart from these cases, the mood selected for finite complement clauses is the same in the two varieties. That is, verbs of the classes listed in (11), as well as nouns and adjectives with the same kind of meaning, select indicative, verbs like those listed in (12) admit indicative and subjunctive in its complement clause, and verbs like those listed in (13) select subjunctive:

(11) a. declarative verbs, such as dizer ('to say'), confessar ('to confess'), mencionar ('to mention') ...

b. epistemic verbs that express a positive belief, such as pensar ('to think'), concluir ('to conclude'), inferir ('to infer') ...

c. verbs expressing commitment, such as prometer ('to promise'), ameaçar ('to threaten'), decidir ('to decide') ... 
d. epistemic factive ${ }^{1}$ verbs, such as adivinhar ('to guess'), descobrir ('to find out'), esquecer ('to forget'), ignorar ('to ignore'), lembrar ('to remember'), saber ('to know') ...

acreditar ('to believe'), admitir ('to admit'), suspeitar ('to suspect') $\ldots$

(13) a. verbs expressing desire, such as esperar ('to hope'), querer ('to want'), suplicar ('to implore'), ...

b. directive verbs, such as exortar ('to exhort'), mandar ('to order'), pedir ('to ask'), recomendar ('to recommend') ...

c. verbs expressing authorisation, such as permitir ('to allow'), consentir ('to tolerate') ...

d. verbs expressing advice, such as aconselhar, sugerir ('to suggest') $\ldots$

e. verbs associated with the expression of cause, such as bastar ('to be enough'), implicar ('to imply'), motivar ('to motivate'), evitar ('to avoid'), impedir ('to prevent') ...

f. verbs as recear and temer ('to fear')

g. non-epistemic factive verbs such as agradar ('to please'), apreciar ('to appreciate'), chocar ('to shock'), espantar ('to astonish'), estranhar ('to find strange'), incomodar ('to disturb'), lamentar ('to regret'), lastimar ('to deplore') surpreender ('to surprise') ...

h. verbs expressing doubt, such as duvidar ('to doubt')

i. negative declarative verbs, such as negar ('to deny')

\footnotetext{
${ }^{1}$ The label 'factive verb' is being used as defined in Karttunen (1971): factive verbs are those whose complement proposition is taken to be true, regardless of the truth value of the main clause. In other words, factive verbs are those which allow the inference that their complement proposition is true, regardless of the affirmative character of sentences of which they are the main verb. This property can formally be expressed as follows (where $V$ stands for the factive verb and $p$ for the complement proposition):

$[[\mathrm{V}(\mathrm{p}) \Rightarrow \mathrm{p}] \wedge[\neg \mathrm{V}(\mathrm{p}) \Rightarrow \mathrm{p}]]$

Thus, for instance, the verbs to regret and to know are factive verbs, but the verbs to want and to assume are not.
} 


\section{Traditional analyses of mood selection}

One of the most proclaimed hypotheses regarding mood selection, defended by Hooper (1975), Klein $(1975,1990)$ Bybee and Terrell (1990), Panzeri (2003), among others, is that the choice of mood is related to a speech act. Roughly, the idea is that indicative is the mood selected for assertive contexts, subjunctive being the mood of non-assertion.

While acknowledging that this proposal is reasonably grounded, several authors point out a few problems for this explanation. In the first place, it does not explain the selection of indicative in some non-assertive contexts, as interrogatives, (cf. Palmer (1986)). In the second place, as Farkas (1992) observed, the proposal fails to explain the selection of indicative, in several languages, including European Portuguese, by the verbs to dream or to imagine, among others, that she calls 'fiction verbs'. In the third place, if indicative is selected for assertive contexts, and given the fact that verbs like to know or to find out select indicative, the concept of assertion may be subject to inquiry. For instance, in sentence (14), the verb to know takes as complement a proposition that is necessarily known prior to the utterance:

$$
\begin{array}{lllll}
\text { Ele sabe } & \text { que } & \text { nós } & \text { estamos aqui } \\
\text { he knows } & \text { that } & \text { we } & \text { are-IND here }
\end{array}
$$

By uttering (14), the proposition 'we are here' is not given as new information, just like in (15) the complement clause of the verb to regret describes something already known, and, thus, is not asserted:

$\begin{array}{lllll}\text { Lamento } & \text { que } & \text { estejamos } & \text { nesta } & \text { situação } \\ \text { regret } & \text { that } & \text { are-SUBJ } & \text { in-this } & \text { situation }\end{array}$

'I regret that we are in this situation'

The point is that the verb saber ('to know') selects indicative, while lamentar ('to regret') selects subjunctive, and this fact is hardly explained by the proposal that indicative occurs in assertive contexts and subjunctive in non-assertive ones.

Another proposal, defended by Solano-Araya (1982), Palmer (1986), and Bell (1990), among others, is that the selection of mood is related to the degree of belief being conveyed. According to this proposal, a high degree of belief on the truth of the proposition leads to the selection of indicative and a lower degree of belief (that might be non-belief) leads to the selection of subjunctive. If one takes into consideration data from European Portuguese and other Romance languages, it can be seen that this proposal fails to explain the fact that in some contexts subjunctive is selected, despite the fact that the relevant proposition is taken to be true. Such is the case of the complement clauses of factive verbs like lamentar ('to regret'), admirar ('to amaze'), and 
others, or of predicative expressions like ser natural ('to be natural') or ser pena ('to be a pity'), for instance.

The proposal that the indicative mood indicates a positive belief, while the subjunctive indicates the absence or a low degree of belief is related to the idea expressed in traditional grammars that subjunctive is the mood of irreality, virtuality, or some associated notion. As Farkas (1992) notices, a problem for this idea is the fact that in several languages, the indicative is selected by fiction verbs, as (the equivalents of) sonhar ('to dream'), imaginar ('to imagine'), and others, despite the fact that their complement clause does not describe something real. In order to account for the selection of the indicative mood by these verbs, Farkas introduces the notions of 'intensional anchoring' and 'extensional anchoring', which correspond to what Giannakidou (1994) designates by '(non)veridalicality'. The basic idea is that an extensionally anchored proposition is one whose truth value is evaluated with respect to a single possible world, be it the real world or another possible world. If this is the case, then, in Giannakidou's terms, the proposition occurs in a veridical context; otherwise, it occurs in a non-veridical one. On the basis of these notions, Farkas (1992) and Giannakidou (1994) propose, roughly, that the indicative is selected by veridical / extensional anchoring verbs, while subjunctive is selected by non-veridical / intensional verbs, that is, verbs that do not allow the inference that their complement proposition is taken to be true in a particular world.

The hypothesis defended by Farkas and Giannakidou explains the distribution of indicative and subjunctive in complement clauses in languages as Rumanian, Hungarian or (Modern) Greek. However, it does not completely explain the selection of mood in several other languages, including European and Brazilian Portuguese. In fact, as regards European Portuguese, as well as other Romance languages, subjunctive is selected for some veridical contexts, like the complement propositions of (the equivalents of) to regret, to be a pity, to be good, among many others. As for Brazilian Portuguese, there are other veridical contexts where subjunctive may be found. Such is the case of the complement clause of verbs like supor ('to suppose') or imaginar ('to imagine'), which introduce a proposition taken to be true in a world other than the real one. The point is that these are veridical verbs, in the sense of Giannakidou (1994), or extensional anchoring verbs, in the terminology of Farkas (1992), and, thus, should select indicative, according to the hypothesis of these authors.

Thus, all the considered proposals face problems in explaining the selection of mood both in European and in Brazilian Portuguese.

\section{Towards an explanation}

The hypothesis that I will consider embraces the assumption that the selection of mood is related to the kind of attitude being expressed (in other 
words, that mood is an expression of modality) and that different languages are sensitive to different modal values with respect to mood selection. I will show that the differences between European and Brazilian Portuguese regarding mood selection found are easily explained within this hypothesis.

\subsection{Mood and context sensitivity}

Starting with complement clauses, we can see that, in European Portuguese, all the cases where the indicative mood is selected are associated with the epistemic modality. This becomes more perspicuous if one looks at the verbs that select indicative:

(16) a. pensar ('to think'), concluir ('to conclude') ...

b. dizer ('to say'), confessar ('to confess') ...

c. imaginar ('to imagine'), sonhar ('to dream') ...

d. prometer ('to promise'), decidir ('to decide') ...

e. ignorar ('to ignore'), lembrar ('to remember'), saber ('to know') ...

All these verbs are associated with epistemic modality. That is, they express someone's belief concerning the truth of their complement proposition. Such is clearly the case of the verbs listed in (16a) and (16b), that commit the subject of the main clause to the acceptance of the truth of the complement clause. The same can be said about the verbs listed in (16c), though in this case the acceptance of the truth is relativised to a possible world differing from the real one (cf. Farkas (1992)). As for the verbs listed in (16d), at first sight, they seem to be closer to deontic modality than to epistemic modality, given that they express a commitment to the fulfilment of the situation described by their complement clause, rather than a commitment with the acceptance of the truth of a proposition. Nevertheless, by committing oneself to the fulfilment of an action, one indicates the belief that the proposition expressing such action will become true. In this sense, it might be said that verbs as to promise indicate that the subject of the main clause believes that the complement proposition will be true. Thus, such verbs also convey a value of belief, albeit indirectly. Therefore, they are also associated with epistemic modality. Finally, verbs as those listed in (16e) are also associated with the expression of an epistemic attitude. In fact, verbs as to know, to find out, and others, express the belief, shared by speaker and the subject of the main clause, in the truth of their complement proposition, while the verb to ignore only expresses the speaker's belief in such truth. Thus, all indicative governors express an attitude of belief. That is to say, they create an epistemic modal context.

As for the subjunctive mood, it occurs in a much wider variety of modal contexts. In other words, it is selected by verbs expressing a wider range of kinds of attitude. In fact, it is selected by verbs expressing deontic modality cf. (17a) -, verbs expressing an attitude of desire (boulomaic modality) - cf. (17b) -, verbs expressing an attitude of evaluation (evaluative modality) - cf. 
(17c) -, verbs expressing an epistemic modality - cf. (17d) - and verbs that do not express any of these modal values, as those listed in (17e-f):

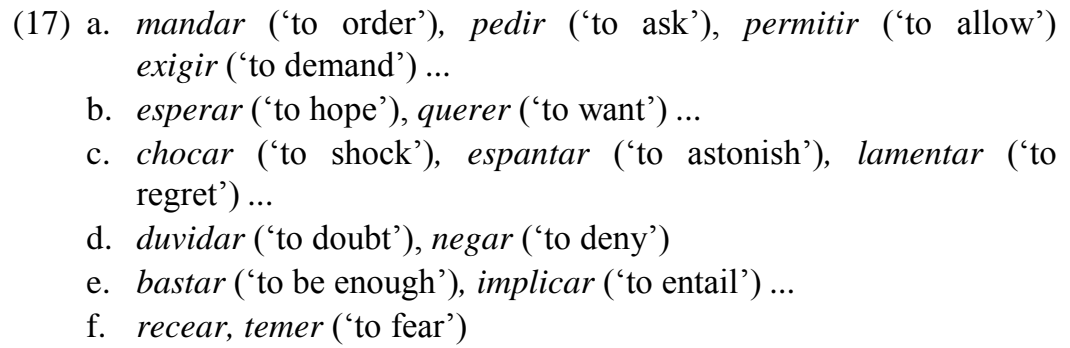

Given this picture, it becomes clear that the indicative is the marked mood, in the sense that it is the one associated with a particular modal value. In accordance, the subjunctive is the default mood, as it occurs in the modal contexts that do not lead to the selection of indicative. In other words, the indicative mood is selected for a particular modal context, namely an epistemic modal context, while the subjunctive is selected for the other modal contexts.

However, it must be stressed that subjunctive may also occur in epistemic modal contexts. In fact, on one side, it is selected by verbs like duvidar ('to doubt') and, on the other side, verbs like acreditar ('to believe') accept both indicative and subjunctive in their complement clause. Thus, the expression of an epistemic attitude is a necessary condition for the selection of indicative, but not a sufficient one. The other condition that must be fulfilled in order for the indicative mood to be selected is that the proposition is taken to be true. In effect, as was already seen, all the verbs that select indicative allow the inference that their complement clause is taken to be true either by the speaker, the subject of the main clause, or both of them, but the epistemic verbs that select subjunctive do not allow such inference. Such is clearly the case of the verb duvidar ('to doubt'), which expresses an attitude of non-belief. As for the epistemic verbs that allow both the indicative and the subjunctive in their complement clause - verbs like acreditar ('to believe'), admitir ('to admit'), suspeitar ('to suspect'), among others -, it might be observed that they select one or the other mood depending on the degree of belief being expressed. In particular, indicative signals a high degree of belief and subjunctive a lower degree. This explains the following contrasts:

(18) a. A Ana acredita sinceramente que ele está em Paris. the Ana believes sincerely that he is-IND in Paris

b. ??/*A Ana acredita sinceramente que ele esteja em Paris. the Ana believes sincerely that he is-SUBJ in Paris

'Ana really believes that he is in Paris' 
(19) a. A Ana acredita the Ana believes que ele está em Paris; aliás, tem quase a that he is-IND in Paris; actually, has almost the certeza.

certainty

b. ??/*A Ana acredita que ele esteja em Paris; aliás, the Ana believes that he is-SUBJ in Paris; actually, tem quase a certeza. has almost the certainty

'Ann believes that he is in Paris; actually she is almost sure'

(20)
acreditar que ele
[It] costs at
believe
that he
consiga sair.
can-SUBJ leave
b. $? ? /$ Custa
[It] costs
$\begin{array}{lll}\text { a } & \text { acreditar que } \\ \text { at } & \text { believe that }\end{array}$
ele consegue sair.
he can-IND leave

'It is hard to believe that he can leave'

In (18) and (19), a high degree of belief is being expressed and subjunctive cannot be selected, while in (20) the opposite situation is verified: a low degree of belief is expressed and subjunctive must be selected.

This being so, the conclusion is that, with regard to verbs associated with epistemic modality, those that express knowledge or belief select indicative while those that express lack of belief (or at least a low degree of belief) select subjunctive.

As for other verbs of sentential complementation, they do not express an epistemic attitude and, therefore, are subjunctive governors. Thus, indicative is the strong, marked, mood, the mood associated with a particular modal value, while subjunctive, associated with a richer variety of modalities, becomes the default mood, occurring in those contexts that do not require the presence of indicative. Such hypothesis can be confirmed by the analysis of mood selection in clausal complements of verbs occurring under the scope of negation.

\subsection{The interference of negation in mood selection}

As is well known, some verbs select different moods in affirmative and negative sentences. Such is the case of the verbs that express an attitude of belief, such as (the equivalents of) to think, to say, to promise, and related verbs, or an attitude of non-belief, such as (the equivalents of) to doubt and to deny.

Verbs of the first kind are indicative governors, but they admit subjunctive if they occur under the scope of negation: 
(21)

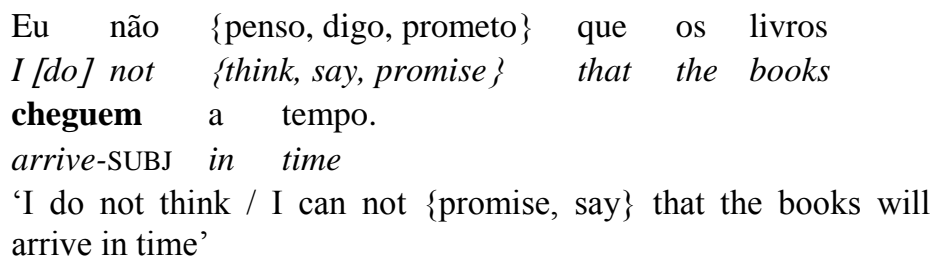

As for the verbs duvidar ('to doubt') and deny ('to deny'), although they are subjunctive governors, they admit indicative in their complement clause if they occur under the scope of negation:

(22) Eu não \{nego, duvido (de)\} que ele perdeu o avião. I [do] not \{deny, doubt(of)\} that he missed-IND the plane 'I do not $\{$ deny, doubt $\}$ that he missed the plane'

The verbs that express an attitude of knowledge - like the equivalents of to know, to find out, to ignore, and others - select indicative both in affirmative and in negative sentences:

(23) a. A Ana não sabia que o Paulo estava em casa. the Ana not knew that the Paulo was-IND at home 'Ana did not know that Paulo was at home'

b. A Ana não ignorava que o Paulo estava em casa. the Ana not ignored that the Paulo was-IND at home 'Ana did not ignore that Paulo was at home'

c. A Ana não descobriu que o Paulo estava em casa. the Ana not find out that the Paulo was-IND at home 'Ana did not find out that Paulo was at home'

Sentential negation is likewise not influential in the mood selection with verbs associated with a non-epistemic modality, such as the equivalents of to regret, to desire, to order and others. This kind of verbs selects subjunctive in affirmative as well as in negative sentences:

$$
\begin{aligned}
& \text { Ele não pediu que } o \text { ajudassem. } \\
& \text { he not asked that him help-SUBJ } \\
& \text { 'He did not ask for help' }
\end{aligned}
$$

These facts are easily explained by the hypothesis that indicative is selected for those contexts that express an attitude of belief, subjunctive being the default mood. 
In fact, regarding verbs like to regret, to ask, to order, and others, they do not express an attitude of belief, no matter whether they occur in affirmative or in negative sentences. Hence, they always select subjunctive.

As for verbs like to know, to remember, among others, they express the belief in the truth of their complement clause, both when they occur in affirmative and in negative sentences. In affirmative sentences, the expression of belief is related to the subject of the main clause and the speaker, while in negative sentences it only concerns the speaker. In reverse, the verb to ignore expresses an attitude of belief concerning the speaker, in affirmative sentences, while in negative sentences the attitude of belief is related both to the speaker and the subject of the main clause. Thus, these verbs, which are epistemic factive verbs, select indicative both in affirmative as in negative sentences, since they always signal an attitude of belief in the truth of their complement proposition, whether this attitude regards only the speaker or both the speaker and the subject of the main clause.

Finally, verbs like to think, to promise, to say, among others, in affirmative sentences, signal an attitude of belief, but in negative sentences they express an attitude of non-belief. Hence, they select indicative in the first case, but subjunctive when they occur under the scope of negation. Conversely, the verbs to doubt and to deny do express an attitude of non-belief in affirmative sentences, but they do express an attitude of belief in negative sentences. Therefore, they select subjunctive in affirmative sentences and indicative in negative ones. In other words, negation reverses the degree of belief being expressed, a fact that leads subjunctive governors to accept indicative and indicative governors to select subjunctive, when they occur in negative sentences.

Nevertheless, it might be observed that, in negative sentences, these verbs may select the same mood that they govern in affirmative sentences. Such possibility exists if negation has a metalinguistic function. That is, if the function of the negative sentence is to correct a previous assertion or a background assumption, the negation operator does not interfere with mood selection. This is illustrated by the following sentences:

$$
\begin{array}{llllll}
\text { Eu não disse que ele está doente, o que disse foi ... } \\
\text { I } & \text { not said that he is-IND sick, } & \text { what [I] said was... }
\end{array}
$$

'I did not say that he was sick, what I said was ...'

$$
\begin{array}{llllll}
\text { Eu } & \text { não } & \text { duvido (de) } & \text { que } & \text { ele esteja doente, } \\
\text { I } & \text { not } & \text { doubt (of) } & \text { that } & \text { he } & \text { is-SUBJ sick, } \\
\text { do } & \text { que } & \text { duvido } & \text { é } & \text { (de) que ... } \\
\text { of } & \text { what } & {[I] \text { doubt }} & \text { is } & \text { (of) that ... }
\end{array}
$$

'I do not doubt that he is sick, what I doubt is that ...'

However, verbs that express an attitude of positive belief can select their mood for affirmative sentences - namely, the indicative mood - even if they 
occur with non-metalinguistic negation. Therefore, in negative sentences, this kind of verbs accept both indicative and subjunctive in the complement clause:

(27) a. Ele não acredita que a Ana esteja em Paris.
he not believe that the Ana is-SUBJin Paris

'He does not believe Ana to be in Paris'

b. Ele não acredita que a Ana está em Paris. he not believe that the Ana is-IND in Paris

'He does not believe that Ana is in Paris'

Both (27a) and (27b) indicate that the subject of the main clause does not accept the truth of the complement clause. In spite of this, (27b), where indicative is selected, allows the inference that the speaker believes in the truth of the complement clause, while (27a) does not allow such an inference. Thus, (27b) expresses an attitude of belief, related to the speaker, while (27a) expresses an attitude of non-belief. Hence, the indicative is selected in (27b) and the subjunctive in (27a).

Things being so, if the speaker and the main subject coincide, then it should be expected that indicative can not be selected, a fact confirmed by sentences like (28):

$$
\begin{aligned}
& \text { (28) a. Eu não acredito que a Ana esteja em Paris. } \\
& \text { I not believe that the Ana is-SUBJ in Paris } \\
& \text { b. *Eu não acredito que a Ana esta em Paris. } \\
& I \text { not believe that the Ana is-IND in Paris }
\end{aligned}
$$

'I do not believe Ana to be in Paris'

However, the following sentence shows that indicative might also be selected even when the individual identified by the subject of the main sentence is the speaker:

$$
\begin{array}{clllllll}
\text { Eu não } & \text { acreditava que a Ana estava em Paris. } \\
I & \text { not } & \text { believed that the Ana was-IND in Paris }
\end{array}
$$

'I did not believe that Ana was in Paris'

The contrast between (28) and (29), about the possibility of the indicative being selected, is related to the intervals of time that are taken into account. In fact, (29) refers to a previous state of non-belief, but the sentence allows the inference that, by the time of utterance, the speaker accepts the truth of the 
complement proposition. Such inference would not be possible if the subjunctive were selected. That is, in (29), two states of belief are brought into consideration. By selecting the indicative, the speaker says that he now believes something that he did not believe before. Thus, the selection of indicative is justified by the fact that an attitude of belief is being expressed.

\subsection{Explaining the differences between European and Brazilian Portuguese}

According to the hypothesis sustained in the two previous subsections, the indicative is selected, in European Portuguese, with positive epistemic modal contexts, and subjunctive is the default mood. That is, indicative is selected for propositions that are taken to be true and occur in an epistemic modal context, subjunctive being selected in the other contexts. In other words, in European Portuguese two necessary conditions apply in the selection of indicative: the existence of an epistemic modal context and the acceptance of the truth of the proposition. Neither the existence of an epistemic context nor the attitude towards the truth, taken in isolation, is a sufficient condition for the selection of indicative in European Portuguese. In fact, it is possible that the sentence is taken to be true and subjunctive is selected (cf. the complement clause of factive verbs like lamentar ('to regret')) and it is also possible that the sentence occurs in an epistemic context and subjunctive is selected (cf. the complement clause of duvidar ('to doubt'), for instance). Indicative is only selected if both of the conditions are fulfilled. If the sentence is not taken to be true or if it is taken to be true but does not occur in an epistemic context, subjunctive is selected.

Considering now Brazilian Portuguese, the data shows the tendency to link mood selection with less restrictive conditions. In fact, in complement clauses, it is possible to select indicative in propositions that do not occur in epistemic modal contexts (cf. (30)), as it is possible to select subjunctive in propositions that are taken to be true, though in a world different from the real one (cf. (31)):

$$
\begin{array}{llllll}
\text { (Que) Bom que ele chegou. } & \text { [BP] } \\
\text { (that) good that he arrived-IND } &
\end{array}
$$

'It is good that he arrived'

$$
\begin{array}{lllll}
\text { Imaginemos } & \text { que } & \text { hoje } & \text { seja } & \text { domingo. } \\
\text { imagine } & \text { that } & \text { today } & \text { be-SUBJ } & \text { Sunday }
\end{array}
$$

'Let us imagine that today is Sunday'

These examples show the Brazilian Portuguese tendency to select indicative if the sentence is taken to be true in the real world, and subjunctive 
otherwise. Notice that this is only a matter of tendency, insofar as - just like it also happens in European Portuguese - on one side, verbs like to imagine may be indicative governors, and, on the other side, subjunctive may occur in propositions that are taken to be true, but do not occur in an epistemic context, as shown by (32):

(32) $[\ldots]$ é natural que existam pessoas que pensem de
is natural that exist-SUBJ persons that think-SUBJ of forma diferente. (Lula Vieira, “DOMINGO”, Jornal do Brasil, way different 11 June 1999)

'It is natural that there are people with different ideas'

If the number of languages taken into consideration is enlarged, it can be seen that European Portuguese follows the pattern also found in other Romance languages, while Brazilian Portuguese is closer (though not identical) to the pattern found in languages such as Rumanian, Hungarian or (Modern) Greek.

Concerning Rumanian and Hungarian, the selection of indicative or subjunctive is conditioned by the concept of veridicality (or extensional / intensional anchoring), as Farkas has shown, and the same happens in (Modern) Greek, as signalled by Giannakidou. That is, in these languages, indicative occurs in veridical contexts and subjunctive in non-veridical ones. In other words, indicative is selected if the sentence is taken to be true, whether its truth respects the real world or a different possible world.

Concerning French, Italian, Spanish, Catalan and European Portuguese, the concept of veridicality is also important to explain mood selection, since indicative occurs only in veridical contexts, but there is another value that rules mood selection, namely, epistemic modality. That is to say, in these languages, indicative occurs in veridical epistemic contexts. Thus, the main difference between Rumanian, Hungarian and (Modern) Greek, on one side, and European Portuguese and most other Romance languages, on the other side, respects the mood selected by factive verbs. In the first group of languages, all factive verbs select indicative, since they create a veridical context, while in the second group only epistemic factive verbs do select this mood. That is, in Hungarian, Rumanian and (Modern) Greek, the equivalents of to regret, for instance, are indicative governors, but in most Romance languages subjunctive is selected, since to regret is not an epistemic verb. As for factive verbs like to know, they select indicative in all languages under consideration, since they are (epistemic) veridical verbs.

This shows that in the group of languages that includes Rumanian and (Modern) Greek the mood system is more closely related to the mere truth value of the proposition than it is in European Portuguese and other Romance 
languages. In this sense, the observed data of Brazilian Portuguese reveals that this variety of Portuguese is becoming closer to the pattern found in Rumanian and other languages than to the one found in European Portuguese. Indeed, as shown above, some data of Brazilian Portuguese suggests the tendency to select indicative only if the sentence is taken to be true.

Nevertheless, considering the observed data, the pattern found in Brazilian Portuguese is different from the one of Rumanian and related languages. In fact, while in these languages indicative is selected for veridical contexts that is, indicative is selected if the proposition is taken to be true in the real world or in a fictional one - in Brazilian Portuguese it is selected only for a sub-group of veridical contexts, namely for veridical propositions anchored to the real world.

Table I summarises the observations made with respect to mood selection in the languages under consideration:

\begin{tabular}{|c|c|c|c|c|}
\hline & \multicolumn{4}{|c|}{ Context where the proposition $\boldsymbol{P}$ occurs } \\
\hline & \multicolumn{3}{|c|}{ Veridical } & Non-veridical \\
\hline & \multicolumn{2}{|c|}{ Reality } & Non-reality & \\
\hline & Non-epistemic & \multicolumn{2}{|c|}{ Epistemic } & \\
\hline & (be good that $\boldsymbol{P}$ ) & (know that $\boldsymbol{P}$ ) & (imagine that $\boldsymbol{P}$ ) & $\begin{array}{l}\text { (want that } \boldsymbol{P}, \\
\text { doubt that } \boldsymbol{P})\end{array}$ \\
\hline Rumanian, ... & \multicolumn{3}{|c|}{ INDICATIVE } & SUBJ. \\
\hline $\begin{array}{l}\text { Brazilian } \\
\text { Portuguese }\end{array}$ & \multicolumn{2}{|c|}{ INDICATIVE } & \multicolumn{2}{|c|}{ SUBJUNCTIVE } \\
\hline $\begin{array}{l}\text { European } \\
\text { Portuguese, ... }\end{array}$ & SUBJ. & \multicolumn{2}{|c|}{ INDICATIVE } & SUBJ. \\
\hline
\end{tabular}

Table I

Modal contexts and selection of indicative or subjunctive in complement clauses

In all languages under consideration the selection of mood depends on the modal context where the proposition occurs. That is, mood is sensitive to the modal context. What distinguishes them is the modal feature(s) that mood is sensitive to. More precisely, the indicative is sensitive to veridical contexts in languages like Rumanian, Hungarian or (Modern) Greek, while in other languages taken into account here a partition in the veridical contexts is observed. In fact, in European Portuguese, as well as in Catalan, French, Italian and Spanish, veridical contexts split into epistemic and non-epistemic ones, while in Brazilian Portuguese, the significant boundary is established 
between propositions that are taken to be true in the real world and those that are not.

Briefly, in languages like Rumanian, the indicative occurs in veridical contexts, in European Portuguese and other languages, it is selected for veridical epistemic contexts, and in Brazilian Portuguese the tendency is to select indicative only for veridical propositions anchored to the real world.

Other data from Brazilian Portuguese confirm the tendency to avoid the indicative if the proposition does not express reality. In (33), the complement clause of a declarative verb exhibits subjunctive, since the truth of the proposition is not taken for granted:

$$
\begin{aligned}
& \begin{array}{l}
\text { Seria exagero } \\
\text { be exaggeration } \\
\text { (to) say that the minister }
\end{array} \text { [...] has-SUBJ } \\
& \begin{array}{l}
\text { corrido o risco de ser demitido. } \\
\text { run the risk of be dismissed }
\end{array}
\end{aligned}
$$

'It would be exaggeration to say that the minister $[. .$.$] has run the$ risk of being dismissed'

Notice that declarative verbs are indicative governors, both in Brazilian and European Portuguese. The selection of subjunctive in (33) is explained by the tendency, in Brazilian Portuguese, to select indicative only for those contexts that express reality.

The same explanation may be given for the selection of mood in (34):
(34) a. Da mesma forma agem os inibidores da enzima of-the same way act the inhibitors of-the enzyme integrase, que atuariam na etapa em que o HIV integrase that act-COND at-the step in which the HIV
insere seu material genético dentro da célula [...]. [BP] inserts its material genetic inside of-the cell

(IstoÉ, 15 March 2000, 1996)

$\begin{array}{rllllll}\text { b. [...] que actuarão na etapa em que } & {[\ldots]} \\ \text { that } & \text { act-IND } & \text { at-the } & \text { step in which } & {[\ldots]}\end{array}$

'In the same way act the inhibitors of the enzyme integrase, that will act at the step when the HIV inserts its genetic material inside the cell' 
Since the speaker does not want to completely commit himself to the truth of the proposition, in Brazilian Portuguese, the conditional mood is selected, while in European Portuguese the indicative future is selected.

Finally, observe the following sentence, which also shows that in Brazilian Portuguese indicative is avoided if the proposition is not given as true:
(35) Quem sabe, agora, [...] novos prazeres também possam who knows, now, [...] new pleasures also may-SUBJ ser compartilhados? be shared

(Regina N. Lins, JB Online, 20 Feb. 2000)

'Who knows if, now, new pleasures may also be shared?'

In European Portuguese, indicative would be selected, since the proposition occurs in a veridical and epistemic context:

(36) Quem sabe se, [...] novos prazeres também podem ser who knows if, [...] new pleasures also may-IND be

compartilhados?

[EP]

shared

In conclusion, the data shows that the divergence between Brazilian and European Portuguese regarding mood selection affects several kinds of sentences, but might be explained by a single factor. That is, both in European and Brazilian Portuguese, indicative is the marked mood, the one that occurs in particular modal contexts, but the modal values that the indicative mood is sensitive to in Brazilian Portuguese and in European Portuguese are not the same. In fact, Brazilian Portuguese shows the tendency to select indicative for those contexts that express reality, while in European Portuguese indicative is selected for all epistemic veridical contexts.

\section{Conclusion}

Comparing European and Brazilian Portuguese, the differences concerning mood selection emerge in sentences that express one of the following possibilities:

(i) the proposition is taken to be true in the real world, but the attitude being conveyed is a non-epistemic one (cf. (37a-b));
(37) a. Bom
que você
veio.
[BP] good that you
came-IND 
$\begin{array}{lll}\text { b. É bom que tenhas vindo. } & {[\mathrm{EP}]} \\ \text { is good that has-SUBJ come } & \end{array}$

'It is good that you came'

(ii) the complement proposition of an epistemic verb is taken to be true in a possible world different from the real one, where the proposition is taken to be false (cf. (38a-b));

$\begin{array}{llllll}\text { (38) a. Imaginemos que hoje } & \text { seja } & \text { domingo. } & \text { [BP] } \\ \text { imagine } & \text { that today } & \text { is-SUBJ } & \text { Sunday } & \\ & & & & \\ \text { b. Imaginemos que hoje } & \text { é } & \text { domingo. } & \text { [EP] } \\ \text { imagine } & \text { that today } & \text { is-IND } & \text { Sunday } & \end{array}$

'Let us imagine that today is Sunday'

(iii) the truth value of the proposition regards the real world, but the certainty of its truth is not expressed (cf. (39a-b)).

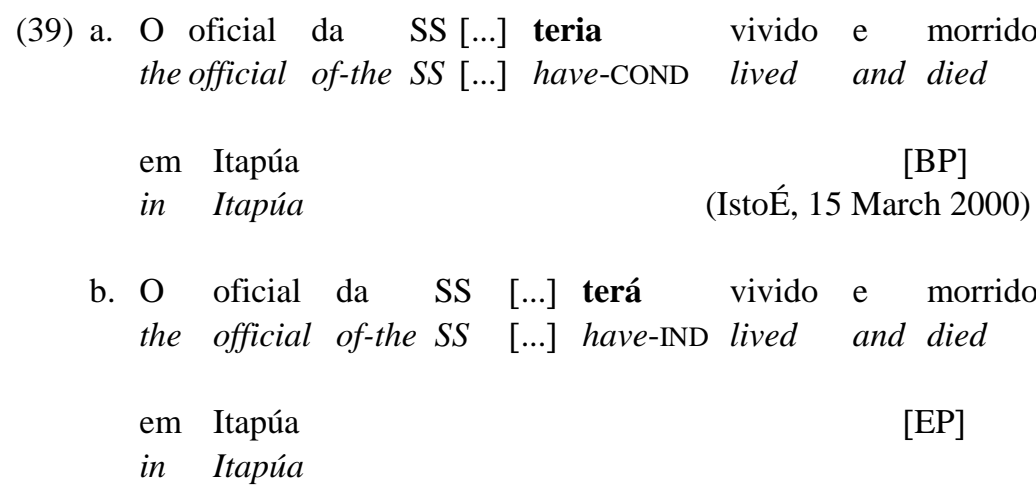

'Allegedly, the official of the SS has lived and died in Itapúa'

As the examples show, in case (i), subjunctive is selected in European Portuguese, while indicative may occur in Brazilian Portuguese. In cases (ii) and (iii), indicative is selected in European Portuguese, but not necessarily in Brazilian Portuguese, where the subjunctive or the conditional mood is preferred.

As said before, these differences suggest the tendency, in Brazilian Portuguese, to select indicative only in propositions expressing reality, while in European Portuguese indicative is selected for all contexts of positive epistemic modality (veridical epistemic contexts). 


\section{References}

Bell, A. (1990) El modo en español: consideración de algunas propuestas recientes. In Indicativo y subjuntivo (Ignacio Bosque, editor), pp. 81-105. Madrid: Taurus Universitaria.

Bybee, J. \& T. D. Terrell (1990) Análisis semántico del modo en español. In Indicativo y subjuntivo (Ignacio Bosque, editor), pp. 145-163. Madrid: Taurus Universitaria.

Farkas, D. (1992) On the semantics of subjunctive complements. In Romance Languages and Modern Linguistic Theory (P. Hirschbühler and K. Koerner, editors), pp. 71-104. Amsterdam: John Benjamins.

Giannakidou, A. (1994), The semantic licensing of NPIs and the Modern Greek subjunctive, Language and Cognition, 4, yearbook of the Research Group for Theoretical and Experimental Linguistics. University of Groningen.

Hooper, J. B. (1975) On assertive predicates. In Syntax and Semantics 4 (P. Kimball, editor), pp. 91-124. New York: Academic Press.

Karttunen, L. (1971) The Logic of English Predicate Complement Constructions. Indiana University Linguistics Club.

Klein, F. (1975) Pragmatic constraints in distribution: the Spanish subjunctive. In Papers from the IIth regional meeting, pp. 353-65. Chicago Linguistic Society.

Klein, F. (1990) Restricciones pragmáticas sobre la distribución del subjuntivo en español. In Indicativo y subjuntivo (Ignacio Bosque, editor), pp. 303-315. Madrid: Taurus Universitaria.

Palmer, F. (1986) Mood and Modality. Cambridge: Cambridge University Press.

Panzeri, F. (2003) In the (Indicative or Subjunctive) Mood. In Proceedings of the Conference "sub7 - Sinn und Bedeutung". Arbeitspapier Nr. 114, FB Sprachwissenschaft, Univ. Konstanz, Germany (Matthias Weisgerber, editor).

Solano-Araya, J. (1982) Modality in Spanish: An Account of Mood. PhD diss., University of Kansas. Ann Arbor: UMI.

Universidade de Lisboa, Portugal

Rmarques@fl.ul.pt 